\title{
REPERCUSSIONS OF THE APPROVAL OF THE STRUCTURE OF THE MERCOSUR INSTITUTE OF PUBLIC POLICIES ON HUMAN RIGHTS BY THE BRAZILIAN GOVERNMENT
}

\section{REPERCUSSÕES DA APROVAÇÃO DA ESTRUTURA DO INSTITUTO DE POLÍTICAS PÚBLICAS DE DIREITOS HUMANOS DO MERCOSUL PELO GOVERNO BRASILEIRO}

FERNANDA EDUARDO OLEA DO RIO MUNIZ Doctoral student at USP/PROLAM (2019) under advisory of Prof. Victor Gabriel de O. Rodríguez, PhD. L.L.M. in Constitutional Law by PPGD/UNIFOR. Fellow at the Center of International Studies of the University of Fortaleza.

\section{ANTÔNIO WALBER MATIAS MUNIZ}

Professor of Law in International Relations at CCJ/PPGD of the University of Fortaleza. Postdoctoral Researcher by UnB/IREL. PhD by USP/PROLAM. Coordinator of the Center of International Studies of the University of Fortaleza.

\section{ABSTRACT}

This paper brings to light the issue of strengthening human rights policies in the Mercosur regional environment through the ratification by the President of the Republic of Brazil, in 2017, of the Mercosur Institute of Public Policies on Human Rights (IPPDH). The said structure was ratified only seven years after the decision had been consensually passed at the regional level. The paper's main aim is to show the reflections of the late ratification of the IPPDH structure by the Brazilian government, and outline the prognoses for the body. It is supported by bibliographic research, as well as by official documents obtained in institutional websites such as those of Mercosur, IPPDH, UN, and Brazilian Federal Senate. It was found out that 
the slowness in the implementation of the said treaty had impacts on the effectiveness of Human Rights policies in the region, such as life improvement for members of the bloc, and the consolidation of the Institute's own budget. Thus, IPPDH has been availing itself of funds raised through specific projects with the Fund for Structural Convergence and Strengthening of the Institutional Structure (FOCEM), which limits the bloc's actions. Although the IPPDH's initiative of counting on the support of FOCEM's investments is a non-definitive modality for the eradication of existing asymmetries, which are more present in less developed countries, it is understood that, although Brazil faces a democratic deficit, its full participation can establish more solid actions and produce more satisfactory results in order to strengthen the integration amongst member states.

KEYWORDS: IPPDH; Mercosur; FOCEM; Human Rights.

\section{RESUMO}

O presente trabalho traz à lume a questão do fortalecimento das políticas de direitos humanos no ambiente regional mercosulino a partir da ratificação pelo Presidente da República do Brasil em 2017, da estrutura do Instituto de Políticas Públicas de Direitos Humanos do Mercosul (IPPDH). Referida estrutura só foi ratificada após sete anos da decisão ter sido aprovada consensualmente em âmbito regional. The paper's main aim is to show the reflections of the late ratification of the IPPDH structure by the Brazilian government, and outline the prognoses for the body. Apoiase em pesquisas bibliográficas e também em documentos oficiais obtidos em sites institucionais como o do Mercosul, IPPDH, ONU e Senado Federal brasileiro. Verificou-se que a leniência na incorporação do tratado em comento, ocasionou impactos na efetivação de políticas de Direitos Humanos na região, como a melhora na vida dos integrantes do bloco e a consolidação do orçamento próprio do instituto. Sendo assim, o IPPDH vem se valendo financeiramente da captação de recursos por meio de projetos específicos junto do Fundo de Convergência Estrutural e Fortalecimento da Estrutura Institucional (FOCEM), o que limita a suas ações no Bloco. Muito embora a iniciativa do IPPDH em contar com o apoio de investimentos 
do FOCEM seja uma modalidade não definitiva para a erradicação das assimetrias existentes, as quais são mais presentes em países menos desenvolvidos, entendese que embora o Brasil enfrente um déficit democrático, a sua participação plena poderá estabelecer ações mais sólidas e produzir resultados mais satisfatórios e com o fim de fortalecer a integração entre os Estados Partes.

PALAVRAS-CHAVE: IPPDH; Mercosul; FOCEM; Direitos Humanos.

\section{INTRODUCTION}

The internationalization of Human Rights is a topic that has taken over the international agenda since the post-war period in 1945. The creation of the UN meant a thorough paradigm shift, where the logic of the States' absolute sovereignty was replaced by the strategy of cooperation for international peace and security, and protection of human rights as a global agenda. Such event later resulted in the creation of institutions which predated the modern protection system of International Human Rights Laws: humanitarian law, the League of Nations and the ILO. As a result, regional human rights protection systems emerge, which complement the UN system, among which we can mention the American system of which Brazil and Mercosur member States are part.

The post-1945 period also brings the start of the Cold War and of the globalization process, when a need arises to advance the cooperation between States from then on based on democratic values. Since then, integration processes emerge on behalf of the economic strengthening of the countries that had been devastated in the War, which open their borders and start to set up international organizations aimed at regional integration, with the purpose of making it possible to increase competitiveness, negotiation power, and market expansion.

In Europe, the European Union (1992) stood out, whereas in South America, Mercosur (1991) stand out, organized by a treaty known as the Treaty of Asunción, whose aim is to create a common market between Argentina, Brazil, Paraguay and Uruguay, and the foresees the development and social justice as consequences of 
integration. It follows the precept of social justice referred to in the Treaty of Asunción in order to explain the evolution of human rights in Mercosur that takes place up to the construction of IPPDH (Institute of Public Policies on Human Rights).

Given the need to take measures that ensure the promotion and protection of human rights in Mercosur, three protocols came to represent this ideal, namely: the Protocol of Ushuaia on the Democratic Commitment in Mercosur, Bolivia and Chile (1998), the Protocol of Asunción on the Commitment to the Protection and Promotion of Human Rights in Mercosur (2005), and the Protocol of Montevideo on the Commitment to Democracy in Mercosur, also known as Ushuaia II (2011). Finally, the Mercosur's commitment to the promotion of human rights resulted in the creation of the Institute of Public Policies on Human Rights (IPPDH), which works as a technical instance of the Meeting of High Authorities on Human Rights and Chancelleries of Mercosur and Member States (RAADH) and which provides support in the implementation of public policies resulting from initiatives, proposals, and activities aimed at the promotion and protection human rights developed within the RAADH's framework.

For the IPPDH to commence its full activities, an institutional structure was established in 2010 by CMC. The Brazilian ratification, however, only came in 2017, a fact that hindered the consolidation of the body's budget, which then started to receive support from the Mercosur Structural Convergence Fund (FOCEM) to finance its projects.

The main goal of this paper is to show the repercussions of the late ratification of the IPPDH's institutional structure by Mercosur, and outline the prognoses for it. The specific goals are: to show that social justice sought for by the Treaty of Asunción as a result of integration is a concept that needs to be worked on throughout the integration process; that the integration only takes place where democracy is present, and the integration needs the support of human rights in order to consolidate and produce benefits to the Member States populations.

The methodology of this paper is grounded on the following investigative strategies: it is a bibliographic review, since it uses theoretical references to explain the problem, besides being based on analyses of Mercosur treaties, CMC decisions, Brazilian laws, as well as on information gathered from the IPPDH and FOCEM 
institutional websites, and newspaper articles; it is historical, because it starts from the understanding of past events such as the Peace of Westphalia until the creation of the United Nations and regional human rights protection systems in order to understand the evolution of these rights and how they are dealt with presently, more specifically, within an international organization for regional integration, in this case, within Mercosur; it is qualitative, since it analyzes the slowness of Brazil in ratifying the IPPDH's institutional structure and the consequences thereof, as well as outlining prognoses; it is descriptive, since it portrays the workings of the Mercosur's human rights system, and, specifically, IPPDH's.

The paper is divided into three chapters, apart from the introduction and conclusion. The first chapter makes a brief historical reconstitution of the internalization of human rights, from Westphalia to the creation of IPPDH in Mercosur; the second chapter describer the evolution of human rights in Mercosur, starting with the analysis of the Treaty of Asunción until the protocols which are related to the human rights topic. Finally, the last chapter discusses the IPPDH, the foundations of its creation, structure and goals, and also shows the results of the late implementation of its structure in the Brazilian legal order, the consequences of such an event, and puts forth some prognoses for IPPDH.

\section{THE INTERNATIONALIZATION OF HUMAN RIGHTS: FROM WESTPHALIA TO THE CREATION OF IPPDH IN MERCOSUR}

The international approach to the protection of human rights and its robust and consolidated structure which is currently in effect derived from gradual achievements marled by important historical events, among which we can cite more ancient ones such as the Peace of Westphalia (1648), and the Congress of Vienna (1815), the creation of humanitarian law (1863), of the League of Nations (1919), of the International Labor Organization (ILO, 1919) and, lastly, the advent of the United Nations (UN, 1945).

The Westphalia Peace treaties have an important meaning for international relations in the contemporary State, for human rights, and for International Law itself, 
since it resulted from the end of the Thirty Years' War between Catholics and Protestants, and established two principles that came to strengthen the idea of peace of international law, the principle of legal equality among European States, and the ban on the use of force. ${ }^{1}$

As early as 1815, another movement for peace among the States took place - the Congress of Vienna, which "marked the end of Napoleonic Wars and established a new multilateral system of political and economic cooperation in Europe" (MAZZUOLI, 2016, p. 77). Add to this the fact that the Congress ended with a multilateral agreement among European States which not only condemned slave trade, given the violation it represented to the principles of humanity and universal morals, but also committed themselves to end it, a remarkable feat, since the conjuncture of that time has slave labor as its main income source (OLIVEIRA et al, 2017, online).

More recently, it is worth mentioning the historical precedents of the modern system of protection of International Human Rights Law, namely: humanitarian law, with the aim of imposing limits to the actions of States at war as a means of ensuring the protection of fundamental rights; the League of Nations, an international organization that aimed to promote international cooperation, peace and safety, whose 1920 Convention covered contents about human rights, especially regarding minority systems and decent working conditions for men, women and children; and, finally, the ILO, which tried to standardize working conditions and well-being internationally (PIOVESAN, 2015, p.189-191).

It is especially important to state that the last three of the aforementioned historical precedents have had repercussions on the restraint of arbitrariness typical of the Nation State, the absolute State, sovereign and only subject of international law. Such paradigms are broken with, and from then on the State is no longer considered in an isolated manner, without any contextualization with the world. From then on, the logic in effect is that of international cooperation, the protection of human

\footnotetext{
1 A war motivated by religious conflicts between Catholics and Protestants in the European mainland. The conflicts ended with the recognition that religions impositions no longer corresponded to the new reality of expansion of monarchic power.
} 
rights by an international system, the insertion of individuals as international law subjects, bearers of international legal personality (MAZZUOLI, 2017, p. 63).

The defining circumstance that resulted in the contemporary approach to International Human Rights Law is historically located much before the occurrence of regional integration and the formation of economic blocs; it stems from the results of both World War I and World War II, in the first half of the 20th century. ${ }^{2}$ The atrocities and effects arising from these two nefarious events were decisive in awakening people to the need and urgency of creating an international regulation for the protection of human rights.

From then on, still in the 20th century, international protection systems start to arise. The pioneer is the UN system, which is global; immediately afterwards, come the regional systems, whose jurisdiction is linked to a given geographical location, namely: Inter-American, European, and African. As a result, more recently, already in the 21st century, specific institutes were created for the protection of human rights within regional integration bodies, which is exemplified herein as the subject matter of this article, the Mercosur Institute of Public Policies on Human Rights (IPPDH).

The scars of unprecedented extermination, torture, and all kinds of deprivation and massacre such as the Holocaust, which decimated 11 million people, 6 million of which were Jews, brought to light the need to limit the State's actions on behalf of recomposing human dignity, as underlined by Piovesan:

The barbarity of totalitarianism meant the rupture of the paradigm of human rights, by means of a denial of the human person's value as the essential value for the law. In face of such a rupture, the need emerges to rebuild human rights as an ethical reference and paradigm that brings law closer to morals. In this scenario, the biggest right comes to be, according to Hannah Arendt's terminology, the right to have rights, i.e., the right to be a subject of rights $(2015$, p. 196).

From this landmark, the concept of absolute sovereignty of the States begins to be deconstructed more diligently, as the protection of human rights becomes an

2 Besides the post-War period, the end of the Cold War and the expansion of globalization also contributed with the internationalization of human rights. 
international agenda and, as it were, demanding a regulation that could have real effects. In sum, the post-War period revealed the importance of international cooperation from the dissemination of international organizations as means of approximation for reciprocal development. They are organized by multilateral treaties, among which the UN is the pioneer and most important in history.

The United Nations, founded on 24 October 1945, right after World War II and with a structure similar to that of the League of Nations, represented the consensus among countries that war only brings devastation and tragedy, and its results do not produce any benefits. Such consensus propitiated the unity on behalf of international peace and safety, which are the motto of the organization and are provided for in the preamble of the United Nations Charter. The UN's purposes, as provided for in article 1, are: To maintain international peace and security; to develop friendly relations among nations based on respect for the principle of equal rights and self-determination of peoples, and to take other appropriate measures to strengthen universal peace; to achieve international co-operation in solving international problems of an economic, social, cultural, or humanitarian character, and in promoting and encouraging respect for human rights and for fundamental freedoms; to be a center for harmonizing the actions of nations in the attainment of these common ends. The UN Charter's commitment to safeguard human rights at the international level is therefore clear, a fundamental contribution in the development of International Human Rights Law.

Shortly thereafter, in 1948, with the aim of providing a more accurate support regarding the definition of "human rights" and "fundamental freedoms" provided for in the UN Charter, the Universal Declaration of Human Rights was proclaimed. It is worth making some considerations about the 1948 Universal Declaration:

[...] it aims to outline a public world order founded on the respect to human dignity by consecrating basic universal values. Starting in its preamble, the dignity inherent to every human being, holder of equal and inalienable rights, is affirmed. It is worth saying that, for the Universal Declaration, the condition of a person is the one and only requisite for holding rights (PIOVESAN, 2015, p. 216). 
By choosing dignity as the basis of all its structure, the 1948 Universal Declaration removes the individual from the level of a subject of the State and puts the State as a subject of the individual, since it recognizes their value, autonomy, and ensures the compliance with rules that are aimed at the individual's own well-being. Furthermore, the limitation of the State's power on behalf of the value of human dignity began to be seen in the constitutional plans of Western States as well. Therefore, the 1948 Universal Declaration had an impact on both the international and domestic plans. In the former, the Declaration corresponds to a legal source for all human rights treaties; in the latter, it is considered as a paradigm to domestic norms for the protection of fundamental rights (MAZZUOLI, 2017, p. 98).

The post-War period, marked by hostilities, then gave way to a new stage in history, which tended to bring States closer to each other, to open dialogue, to cooperation and construction of a new conjuncture grounded on democratic values. This new reality also brought about regional human rights protection mechanisms, with the aim of bringing closer together countries which were geographically close to each other, and with very close historical, cultural and social peculiarities. The regional protection system does not compete with the global system, neither excludes it; on the contrary, they complement each other. Individuals only need to choose the one that brings them the most protection.

Although they were created in accordance with the global system's normative framework $^{3}$, regional systems have their own legal instruments. Brazil is part of the Inter-American regional system, ruled by the 1969 American Convention on Human Rights, which created the Inter-American Commission on Human Rights and the Inter-American Court of Human Rights (PIOVESAN, 2015, p. 335).

It is worth noting that along the post-War history, what is known as Cold War begins and, simultaneously, so does the globalization process. This globalization process intensified between the 1950s and 1990s, and not only revolutionized the social and cultural coexistence in many countries, but also questioned the concept of

3 The current set of normative instruments of the global system is comprised of: the Universal Declaration of Human Rights; the International Covenant on Civil and Political Rights; the International Covenant on Economic, Social and Cultural Rights; and other international covenants (PIOVESAN, 2015, p. 335). 
State itself, which did not allow the opening of borders, a moment when it was proven to be too outdated to tackle the challenges posed by the new world reality.

From then on, international organizations for regional integration start to emerge, such as: Mercosur (1991), the European Union (1992) — the latter replacing the European Coal and Steel Community (ECSC, 1951) - , the European Economic Community (EEC, 1957), and the European Atomic Energy Community (EAEC, 1957). The main goal of these organizations is to overcome the economic problems of Member States inserted into the new world geopolitics by increasing the degree of competitiveness in the international market, since the presence of a significant set of countries has "a bigger negotiation power than what each of these countries would have if they presented themselves individually, being able to defend and prioritize the each one's and their collective interests far more effectively. (OCAMPO, 2009. p. 24). Another advantage is the expansion of markets that begin to trade within the bloc itself, so that they can become stronger and, after that, compete in the global market, a moment when their competitive capacity also develops internationally.

Despite the fact the economic goal stands out within these organizations, it is necessary to add the subject of human rights, was not overlooked: "[...] the European Council, as early as 1950, adopted the European Covenant on Human Rights" (PIOVESAN, 2015, p. 334). With regard to Mercosur, the first evidence of protection of human rights appears in the Protocol of Ushuaia on Democratic Commitment in Mercosur, Bolivia and Chile in 1998. Then, in 2005, the Protocol of Asunción on commitment to the protection and promotion of Human Rights in Mercosur was adopted, which led to the creation of the Institute of Public Policies on Human Rights (IPPDH) and, at last, more recently, in 2011, the Protocol of Montevideo on Commitment to Democracy in Mercosur was adopted.

\section{HUMAN RIGHTS IN MERCOSUR}

Before dealing with Mercosur and human rights on their own, it is necessary to state that its existence could only be considered after the redemocratization that took place in South American countries in the mid-1980s, when the first negotiations 
to place as to bring countries closer to each other in the political and economic planes, headed by Sarney and Alfonsín, and that ended up in the creation of Mercosur in 1991 under the leadership of Collor and Menem. Faced with this, we cannot forget that integration goes pari passu with democracy, and it is impossible to implement the former without the latter.

There is no doubt that Mercosur has, in its genesis, the goal of an exclusively economic integration - so much so that the Treaty of Asunción (the instrument that created Mercosur) was originally entitled Treaty establishing a Common Market between the Republic of Argentina, the Federative Republic of Brazil, the Republic of Paraguay and the Oriental Republic of Uruguay, suggesting that the final goal of the said treaty was the formation of a common market between Member States. ${ }^{4}$ The said treaty does not contemplate any allusions to human rights, there is only a subtle passage in the preamble that mentions economic development with social justice as a result of integration (BRASIL, 2017, online).

In an attempt to clarify the term "social justice", the words of Ban Ki-moon are pertinent:

\begin{abstract}
Social justice is a fundamental principle of peaceful and prosperous coexistence among nations. We defend the principles of social justice when we promote gender equality or the rights of indigenous peoples or migrants. We favor social justice when we eliminate the barriers that people face by reasons of gender or age, race, origin, ethnicity, religion, culture or impairment (ONUBR, 2009, online).
\end{abstract}

The features attributed to social justice are directly imbricated to the value of dignity, which is inherent to human rights. For the Mercosur integration to result in economic development with social justice, it is above all necessary that Member States have a posture aimed at protecting human rights, and also that they carry out institutional work so as to develop public policies que make them viable, otherwise the preamble provisions would not be more than sheer rhetoric.

\footnotetext{
4 In the 21st century, Mercosur was enlarged: in 2012, Venezuela became a full Member State, and, in 2015, Bolivia also asked to enter the bloc. Despite the Bolivia entering protocol having been subscribed by all Member States, it is still pending its incorporation by Bolivia's own legal system. The number of associate members also increased with the entry of Guiana and Suriname in 2013.
} 
As proof of the Mercosur Member States' commitment to the human rights agenda, we have to consider that they are part of both the global system (or UN system) and the Inter-American regional system for the protection of human rights. ${ }^{5}$ Such an engagement from the Member States in the said subject resulted in the creation of instruments to promote and protect human rights in Mercosur.

The first step to insert human rights in Mercosur took place in 1998 with the adoption of the Protocol of Ushuaia on Democratic Commitment in Mercosur, Bolivia and Chile, which, in sum, conditions the existence of Mercosur to the full effectiveness of democratic institutions (art. 1); it is applicable to the relations under the integration agreements in effect between Member States of the Protocol, in the event the democratic order is disrupted in any of them (art. 2); In the event of a rupture in the democratic order, it provides for measures such as the suspension of the right to take part in different bodies of the integration process and even the suspension of rights and obligations under these processes (art. 5), such measures should also be taken by consensus among the Member States in the protocol. Finally, the measures referred to in article 5 will only be interrupted after the agreement from those States that applied the measures that the full reestablishment of the democratic order was verified (art. 7) (MERCOSUL, 2017, online).

The relevance of the Protocol of Ushuaia is to guide the relations within an integrationist bloc with prominently economic goals, so as to state that there is "a minimum material that inform such processes" to be observed during the unfolding of its activities, and that this minimum is the democratic stability within each Member State. The minimum democratic content includes the protection of minorities, which one comes to being upon the effectiveness of human rights (CONCI, 2014, p. 477).

Then, in 2005, Mercosur took another step, or rather, regulated for the first time in an open and clear way about human rights by means of the Protocol of Asunción on the Commitment to the Protection and Promotion of Human Rights in Mercosur. Its scope is to "ensure the protection, promotion and guarantee of human

5 In September 2012, Venezuela denounced the American Human Rights Convention, no longer submitting itself to the jurisdiction of the Inter-American Court of Human Rights from the date its denunciation was formalized. Also, as early as 2017, it also denounced the Charter of the Organization of American States (OAS), requesting is full exit from OAS (which must take about two years from the notification to the Secretary-General), therefore breaking with the Inter-American system of protection of human rights. 
rights, and the fundamental freedoms of all people", emphasizes as indispensable for the consolidation of the integration process the effective enjoyment of fundamental rights (MERCOSUR, 2017, online). It further reaffirms the principles and norms contained in the American Declaration of the Rights and Duties of Man, in the American Convention on Human Rights, and other regional human rights instruments, such as the Inter-American Democratic Charter. Although it is the first Mercosur instrument to approach human rights in a particular way, it has only nine articles and a sanctions system very similar to that provided for in the aforementioned Protocol of Ushuaia, whose maximum measure to be taken against States that violate human rights and fundamental freedoms is, according to article 4, the suspension of the right to participate in the integration process, as well as the suspension of rights and duties under it. The importance of that document is undeniable, as it is revealing of the Mercosur Member States' effort in claiming the responsibility to promote and protect human rights, but, on the other hand, it is possible to see a still rudimentary content, lacking more effective measures to the intended purposes.

Ultimately, and more recently, in 2011, we had the adoption of the Protocol of Montevideo on the Commitment to Democracy in Mercosur, also known as Ushuaia II. This document considers the effectiveness of democratic institutions and the respect to human rights and fundamental freedoms as essential requirements to the effectiveness of the integration process among the parties, and is shown to be in conformity with the understanding of the United Nations General Assembly and Human Rights Council (MERCOSUR, 2017, online).

Ushuaia II is shown to be more comprehensive than "Ushuaia I" (the first protocol referred to in this chapter), because its applicability is not restricted to the situations of disruption or threatened disruption of the democratic order, but encompasses even cases of violation of constitutional order or situations that put the legitimate exercise of power and the effectiveness of democratic values and principles at risk (art. 1).

Article 6, which deals with the disruption of hypotheses of disruption of the democratic order is different from the other, in that it provides for a more robust and committed list of sanctions. Thus, it adds several other hypothesis to that of 
suspension, such as: total of partial closing of land borders; limitation or suspension of trade; promotion of the suspension of the affected party in other regional and international organizations; application of political and diplomatic sanctions, among others (art. 9).

Ushuaia II is the clear display of maturing of the concepts related to the democratic order, human rights and fundamental freedoms as pillars of the integration process. Its effectiveness, however, is still conditioned to the ratification by all signatory States adopting "Ushuaia I", by the Plurinational State of Bolivia and the Republic of Chile. When the respective ratifications are achieved, this Protocol will supersede the first one (art. 11).

\section{IPPDH AND THE CONSEQUENCES OF THE LATE RATIFICATION OF ITS STRUCTURE BY BRAZIL}

Mercosur's commitment to the promotion of human rights also includes the creation of bodies that instrumentalize it, such as the Meeting of High Authorities on Human Rights and Chancelleries of Mercosur and Member States (RAADH) and the Mercosur Institute of Public Policies on Human Rights (IPPDH). Before the creation of RAADH, CMC decision No. 26/03 designated an ad hoc group on human rights to carry out a series of work in the Member States through the interchange of information and experiences, the search for consensus in the forums in which the Member States participated, and the promotion of discussions on the convenience of creating a Right Humans Charter for Mercosur.

Consequently, in 2004, RAADH was created by CMC decision No. 40/04, which can be understood as follows: "it is a space for intergovernmental coordination on public policies of human rights, which gathers the main officials from competent institutions in the field [...] it works as a specialized instance" (RAADH, 2017, online). The result of advances achieved by means of initiatives, proposals, and activities carried out within RAADH, the IPPDH was created by CMC decision No. 14/09.

IPPDH is a technical body that provides support to RAADH so as to enable the implementation of public policies resulting from initiatives, proposals and activities 
carried out within the RAADH's framework. Its goal is to contribute with the strengthening of rule of law in Member States and is also competent to carry out several functions, such as: designing and executing public policies on human rights; implementing means that allow a more effective protection in the promotion of human rights recognized in the Member States' respective constitutions and international human rights instruments; adopting international human rights standards instituted by the Inter-American system and United Nations system; working for the harmonization of Member States' legislation concerning human rights; providing technical support so as to qualify officials from human rights bodies in Member States; offering a space for reflection and dialogue about public policies among public employees and civil society organizations; carrying out studies and investigations about topics related to the promotion and protection of human rights that are requested by RAADH (art. 3). Such IPPDH functions are carried out whenever explicitly required by Member States. Moreover, IPPDH has its own institutional structure, with a permanent office in Buenos Aires and its own budget.

For the IPPDH to commence its full activities, an institutional structure was established by CMC decision No. 12/10. It was, however, pending only the Brazilian ratification, and it was advised by such decision to carry out its incorporation by $1 \mathrm{st}$ August 2011, but in fact it only took place in 2017. The approval of the IPPDH's institutional structure by the Brazilian National Congress took place on 14 June 2017 by Legislative Decree No. 88, and the promulgation by the President of the Republic took place on 30 October 2017 by Decree No. 9184.

Matters related to IPPDH's organization and operation are defined in its institutional structure, the financial costs of which are borne by the government bodies/offices of each Member State government that have competence on the matter (article 5). The definition of the governmental instance responsible for the contributions of each Member State and the amount each one has to provide were determined in the decision that approves the annual budget; in the case of Brazil, the instance responsible for that is the Office of Human Rights of the Presidency of the Republic, which had over $\mathrm{R} \$ 68$ million available to use in 2016 in projects aimed at the promotion of Human Rights, according to data from the federal budget (FEDERAL SENATE, 2017, online). There is no provision, however, for any type of 
transfer of funds to IPPDH until 2016, although the amount due by the Brazilian government has been stipulated in the IPPDH's budget since 2010.

In the meantime, IPPDH used resources from FOCEM (US\$ 500,000) through CMC decision No. 44/12, which ended up financing the project entitled "Building Infrastructure for the Protection and Promotion of Human Rights in Mercosur." It was the first project financed by the Mercosur Fund for Structural Convergence (FOCEM) allocated for a Mercosur institute, and the pioneer on matters of human rights which was developed within its program IV, which is related to the strengthening of institutional structure and integration process.

In short, the scope of the project is thus defined:

[...] it will facilitate the bond between public institutions and between the relationship of these entities with the civil society, favoring the participation in human rights policies. In addition, the Institute has implemented a Virtual Campus dedicated to increasing and integrating the state employees' and social players' technical and political knowledge on matters of public policies for human rights. Finally, IPPDH developed, within this project, the Mercosur Information System on Institutionality in Human Rights (SISUL), aimed at disseminating information on public and social institutions related to human rights and, at the same time, promoting the analysis about this institutionality in MERCOSUR (IPPDH, 2013, online).

It is a very relevant project to Mercosur citizens, who are targeted by the regional integration process. The hard-earned democracy in Member States needs solid support from the affirmation of human rights to be consolidated, and the said project aims to help with it. Thus, IPPDH tries not only to implement the protection of human rights, but also to promote the means that increase its coverage and produce satisfactory results that have a positive impact in the lives of people who are the recipients of the integration process. On the other hand, one has to consider that the Brazilian slowness in ratifying the IPPDH's structure largely reveals the lack of interest in applying public policies on human rights in the region, since it not only hindered the formation of the budget, but also the development of projects in the area.

The Brazilian government's position in dealing with human rights matters has also drawn attention when seen within the current conjuncture, the increasing democratic deficit and human rights violations, such as Ministry of Labor Ordinance 
No. 1129/2017, which made slave labor inspections more flexible by requiring the Labor Minister's explicit determination to do so; by creating bureaucracy for proving conditions analogous to slavery, which was previously done by the inspector simply issuing a report, from then on required a police report to be attached to it; by restricting the scope of the definition of slave labor, casting aside the concepts of the International Labor Organization (ILO) and of the Criminal Code, which were previously used. This ordinance did not stay in effect for long, given the domestic and international pressures, and was quickly replaced by Ministry of Labor Ordinance No. $1293 / 2017$, which revoked the previous one and corroborated the legal previsions on the matter.

Another case is the lack of policies to fight hunger in the poorest regions in the country, and the spike in unemployment due to the economic crisis, which will probably take Brazil back to the Food and Agriculture Organization (FAO) Hunger Map, as FAO Director-General, Brazilian José Graziano da Silva, warns:

If Brazil does not manage to resume its economic growth, generate quality jobs, and have a food security program specifically aimed at the most depressed zones, we may unfortunately go back to the FAO Hunger Map. (AZEVEDO, 2017, online).

This issue, that puts individuals in conditions of vulnerability and is a threat to human subsistence, is a violation of the constitutional right to life, and, consequently, it is the removal of dignity itself.

It is also worth remembering the curtailment of freedom of expression in October 2017, when Brazilian singer Caetano Veloso was prohibited from singing in support of the Homeless Workers Movement (MTST) by decision of the 2nd Tax Authority Court of São Bernardo do Campo, in ABC Paulista, i.e., as he himself declared, it was the first time he had been prohibited from singing since the country's redemocratization.

Furthermore, in May 2017, the repression of demonstrations in Brasília against then President of Brasil Michel Temer resulted in the following comment by the Director of the United Nations Information Center in Brazil, Maurizio Giuliano: "We consider that, in this case, there was excessive use of force, and we are deeply 
worried about it [...] The demonstrator's human rights have to be guaranteed even if the demonstrator's commit crimes" (SENRA, 2017, online).

All the examples mentioned above show that human rights in Brazil are too frail, since the value of dignity that permeates them is constantly under threat in situations that remove the right to life, to physical and psychological integrity, to autonomy, and to equality before the law. Despite the huge difficulties Brazil has undergone in democracy, human rights and fundamental guarantees, one cannot overlook the positive actions that were implemented lately. It is the case of the 2017 Federal Budget, that, for the first time, indicated its financial contribution to IPPDF by allocating $\mathrm{R} \$ 2.5$ million (BRASIL, 2017, online). Now that IPPDH has its own, full budget, it is expected to develop and implement projects that strengthen democracy and human rights that are constantly under threat and are really important issues to Mercosur, whose Member States have a stint of authoritarian regimes in common.

\section{CONCLUSION}

The post-1945 period is undoubtedly a landmark in the development for the system of protection of International Human Rights Law. The creation of the UN represented the consensus among countries that war only brings devastation and tragedy, and its results do not produce any benefits. It was the most significant signal that humanity craved for the existence of peace and safety; in addition, the horrors of World War II had been so atrocious that the need to internationally regulate these rights was a consensus. Later, in 1948, the Universal Declaration of Human Rights is adopted, with the purpose of clarifying the definition of "human rights" and "fundamental freedoms", provided for in the UN Charter, thus consolidating the UN system or global system of protection of human rights, the most important and a precursor for those that were still to come.

The evolution of International Human Rights Law initiated in Westphalia with the establishment of legal equality among the States and the ban on the use of force went through the creation of humanitarian law, of the League of Nations, and of the ILO, having resulted in the existence of modern systems of protection of human 
rights, both the global and regional ones, which complement each other. The concept of an authoritarian, absolute sovereign Nation-State was replaced with the necessary cooperation and search for international peace and safety, and respect for human rights and fundamental freedoms. The Cold War and the expansion of globalization translated the urgency about deeper cooperation, which gave rise to regional integration processes in favor of the States' economic development. The recipients of the integration process, however, did not go unnoticed, or rather, the citizens in Member States, as the promotion and protection of human rights became an essential part of the said process.

The post-redemocratization period in Southern Cone States led to the creation of Mercosur. Therefore, it is possible to talk about integration only where democratic institutions are in perfect order. Despite the economic purposes provided for in the Treaty of Asunción, it also contemplated the social justice approach as a result of integration. Thus, it was verified that social justice is imbricated to the value of dignity, inherent to human rights. The search for this ideal is revealed in the States' engagement in the global and regional systems of protection of human rights, as well as in the Mercosur integration process itself, by adopting protocols that aim to preserve the democratic order, and protect and promote human rights. From this, it was noticed that integration can only be implemented when it is guided by a democratic minimum, and such democratic minimum can only be achieved in an environment where there are effective human rights.

It was verified that IPPDH is a technical body that represents the practical action of Mercosur in the field of human rights, whose goal is to contribute with the strengthening of the rule of law in Member States. Its role is to support RAADH in making viable the public policies resulting from initiatives, proposals and activities carried out within the RAADH's framework.

It was verified that, despite having being created in 2010, IPPDH only appeared in the Brazilian Federal government's budget in 2017, the year when its institutional structure was approved, i.e., there was a 7-year delay in what could have been investment in research, execution of projects, support to the strengthening of human rights within the integration process, and which could have even helped Brazil. It is also worth mentioning the support provided by FOCEM in financing the 
most important IPPDH project in this period, namely, "Building Infrastructure for the Protection and Promotion of Human Rights in Mercosur."

On the other hand, it is believed that the Brazilian contribution guaranteed in 2017 by the Federal Government, one of the largest in Mercosur, can promote an increase in the development of the IPPDH's ideals, showing that Member States are firmly engaged with the commitments assumed internationally, in both the global and regional systems, with each one's efforts shown in the projection of human rights in Mercosur. It is expected that the Brazilian economic contribution and the subsequent consolidation of the IPPDH's budget will enable the strengthening of integration among Mercosur countries through the promotion of projects that aim to restrain human rights violations happening in Brazil and other Mercosur Member States, although they have also been undergoing democratic turbulences and disregard to human rights as a whole.

\section{REFERENCES}

AZEVEDO, Guilherme. UOL notícias, São Paulo, 06 nov. 2017. Política. Avaliable at: <https://noticias .uol.com.br/politica/ultimas-noticias/2017/11/06/desempregopode-recolocarbrasil-no-mapa-da-fome-diz-lider-do-orgao-da-onu-paraalimentacao.htm>. Access on: 07 Nov. 2017.

BRAZIL. Decreto $n^{\circ}$ 350, de 21 de novembro de 1991. Promulga o Tratado para a Constituição de um Mercado Comum entre a República Argentina, a República Federativa do Brasil, a República do Paraguai e a República Oriental do Uruguai (TRATADO MERCOSUL).

Avaliable

at: <http://www.planalto.gov.br/ccivil_03/decreto/1990-

1994/d0350.htm?TSPD_101_RO=987003ae5c7206c704ec8d099ade8574sHj000000 00000000 00c8dfddb5ffff00000000000000000000000000005b0f2d6200efc60aad>. Access on: 13 Dec 2017.

Orçamento da União, exercício financeiro de 2017. Avaliable at: <http://www.planalto.gov.br/CCIVIL_03/Projetos/PLN/2016/Anexos/3 .\% 20PLOA\% 202017 \%2 $\quad$ O $\%$ 20Volume\% 20II.pdf?TSPD_101_RO=35f149e5bf3lca8eecf86a061de7529coml000000000 0000000c8dfdd̄b5ffff00000000000000000000000000005b1419990018ece336/>. Access on: 10 Dec. 2017.

CONCI, Luiz Guilherme Arcaro. Integração em perspectiva substancial na América Latina: os direitos humanos com instrumentos de aproximação de ordens 
internacionais e nacionais. Revista Latino-Americana de Estudos Constitucionais, Fortaleza, n. 16, p. 475-501, 2014.

IPPDH. Projeto IPPDH-FOCEM. Avaliable at: <http://www.ippdh.mercosurint/ptbr/projeto-ippdh-focem/>. Access on: 14 Oct. 2017.

MAZZUOLI, Valério de Oliveira. Curso de direito internacional público. 10. ed. São Paulo: Revista dos Tribunais, 2016.

MERCOSUL. CMC/DEC. $\mathbf{N}^{\circ}$ 14/09 - Instituto de Políticas Públicas de Direitos Humanos. Avaliable at: <http://www.ippdh.mercosur.int/wpcontent/uploads/2014/04/DEC_014-2009_PT_Inst-Politicas-Pub-Direitos-

Humanos.pdf>. Access on: 12 Dec. 2017.

Protocolo de Ushuaia sobre o Compromisso Democrático no Mercosul, Bolívia e Chile. Avaliable at: <http://www.mercosul.gov.br/40normativa/tratados-e-protocolos/123-protocolo-de-ushuaia>. Access on: 15 Dec. 2017.

MERCOSUR. Mercosul/CMC/Dec. $\boldsymbol{N}^{\circ}$ 12/10. Avaliable at: <http://www.mercosur.int/ innovaportal/v/2376/2/innova.front/decisiones-2010>. Access on: 29 Nov 2017.

Protocolo de Montevidéu sobre Compromisso com a Democracia no

Mercosul. Avaliable at: <http://www.mercosurint/msweb/portal\%20intermediario/ Normas/normas_web/Decisiones/PT/CMC_2005-06-

19_NORDEC_17_PT_Prot\%20Assun \%20Diret\%20Hum.PD>. Access on 18 Dec. $20 \overline{17}$.

Protocolo de Montevidéu sobre Compromisso com a Democracia no

Mercosul. Avaliable at: <http://www.mercosurint/innovaportal/file/2486/1/ushuaia_ii.pdf>. Access on: 18 Dec. 2017.

Protocolo de Montevidéu sobre Compromisso com a Democracia no Mercosul (Ushuaia II). Avaliable at: <http://www.mercosurint/innovaportal/file/2486/1/ ushuaia_ii.pdf>. Access on: 20 Dec 2017.

OCAMPO, Raúl Granillo. Direito internacional público da integração. Trad. S. Duarte. Rio de Janeiro: Elsevier, 2009.

OLIVEIRA, Victor A. P. De; BUENO, Elen de Paula. A primeira declaração internacional sobre a abolição do tráfico de escravos. Avaliable at: <http://unespciencia.com.br/2017/10/01/ex-dossie-90/>. Access on: 10 dez. 2017.

ONUBR. Carta das Nações Unidas. Avaliable at: <https://nacoesunidas.org/wpcontent /uploads/2017/11/A-Carta-das-Nações-Unidas.pdf>. Access on: 10 Dec. 2017. 
. Dia Mundial da Justiça Social - 20 de fevereiro de 2009. Avaliable at: <nacoesunidas.org/dia-mundial-da-justica-social-20-de-fevereiro-de-2009/>. Access on: 18 Dec. 2017.

PIOVESAN, Flávia. Direitos humanos e o direito constitucional internacional. 15. ed. São Paulo: Saraiva, 2015.

RAADH. ,Qué es la RAADH?. Avaliable at: <http://www.raadh.mercosur.int/que-eslaraadh/>. Access on: 21 Dec. 2018.

SENADO FEDERAL. Orçamento Federal. Avaliable at: <https://www12.senado .leg.br/orcamento/documentos/loa/2016/elaboracao/projeto-de-lei/proposta-dopoder-executivo/projeto-de-lei/volume-iv-tomo-ii-detalhamento-das-acoes-orgaos-dopoder-executivo-presidencia-da-republica-e-ministerios-exceto-mec/orgaos-dopoder-executivo/64000-secretaria-de-direitos-humanos/view>. Access on: 2 Dec. 2018.

SENRA, Ricardo. 'Houve uso excessivo de força', diz diretor da ONU sobre reação a protesto em Brasília. BBC Brasil, Washington, 26 maio 2017. Avaliable at: <http://www.bbc.com/ portuguese/brasil -40066349>. Access on: 20 May 2017. 